\title{
An immunochemical approach to quantifying predation by euphausiids on the early stages of anchovy
}

\author{
Gail H. Theilacker ${ }^{1}$, N. Chyan Huei Lo ${ }^{2}$, Annie W. Townsend ${ }^{3}$ \\ ${ }^{1}$ Alaska Fisheries Science Center, 7600 Sand Point Way NE, Seattle, Washington 98115-0070, USA \\ ${ }^{2}$ Southwest Fisheries Science Center, 8604 La Jolla Shores Dr., La Jolla, California 92038-0271, USA \\ ${ }^{3}$ Marine Life Research Group, Scripps Institution of Oceanography, La Jolla, California 92093-0201, USA
}

\begin{abstract}
Off southern California (USA), euphausiid crustaceans appear to be significant predators on the early stages of northern anchovy Engraulis mordax. Between 47 and $78 \%$ of the natural mortality of northern anchovy eggs and yolk-sac larvae can be explained by euphausid predation. The incidence of predation was determined from direct evidence provided by an immunochemical technique that detects anchovy remains in individual euphausiids. Rates of predation were determined from euphausiid feeding rates and digestion rates. The impact on the anchovy population was estimated by quantifying predator abundance by species, estimating predator and prey co-occurrence considering the diel migratory patterns of the predator, determining the number of prey removed $\mathrm{d}^{-1}$, and generating natural mortality rates for the anchovy. Euphausiids ate $2.8 \%$ of the anchovy population $\mathrm{d}^{-1}$ in the nearshore area and $1.7 \% \mathrm{~d}^{-1}$ in the offshore area.
\end{abstract}

\section{INTRODUCTION}

Predation may be a major cause of larval fish mortality in the sea, yet the evidence is not conclusive because methods to assess mortality due to predation have been difficult to develop (Hunter 1984, Sissenwine 1984, Bailey \& Houde 1989). Clearly, to discern predator-prey relationships, the predators need to be identified. Direct observation of stomach contents identified planktivorous fish as important predators of fish eggs and larvae (Hunter 1984, Brownell 1985, Dann et al. 1985, Alheit 1987). Likewise, visual analyses of the gastric cavities of gelatinous zooplankters revealed that they can be significant predators on the early stages of fishes (Moller 1984, Purcell 1985, 1989, 1990). Yet predator-prey relationships remain obscure in many situations where predator gut contents cannot be identified through visual analyses.

Direct evidence of predation by carnivorous crustaceans that macerate their prey is limited. In the field, only a few studies report larval fish remains in crustacean guts (Bailey \& Yen 1983, Alvarnno 1985, Yamashita et al. 1985, Yen 1987) despite the array of crusta- cean predators identified in the laboratory (Hunter 1984, Bailey \& Houde 1989).

Crustacean predators of fish eggs and larvae in the sea need to be identified, and their predation rates need to be quantified. Serological methods that raise antibodies against the target prey successfully detected predation by invertebrates (Boreham \& Ohiagu 1978, Feller et al. 1979. Theilacker et al. 1986), and these methods, which yield information on incidence only, can be quantified with additional information (Calver 1984, Sunderland 1988, Theilacker 1988). Recently, Theilacker et al. (1986) developed antibodies to the yolk protein of the northern anchovy Engraulis mordax, detected the yolk protein in the gut of a euphausiid crustacean Euphausia pacifica, and estimated predation rates at a limited field site (Theilacker 1988).

Here we evaluate, spatially and temporally, northern anchovy egg and larval mortality due to predation by the euphausiid assemblage commonly found in the California Current. We collected anchovy eggs and larvae and euphausiids during 2 California Cooperative Oceanic Fisheries Investigations (CalCOFI) sur- 
veys. CalCOFI has been making seasonal measurements of the physical, chemical and biological characteristics of the California Current for more than $40 \mathrm{yr}$. CalCOFI cruises encompass the entire anchovy population during the peak of spawning. We analyzed the standardized plankton collections to estimate prey and predator abundance and applied an immunoassay, ELISPOT enzyme-linked immunospot assay, to identify the predators. We used this information to quantify predation rates. The predator net collected adult euphausiids only for the immunoassay. But because it is common for abundance of juvenile (6 to $11 \mathrm{~mm}$ ) euphausiids to be an order of magnitude higher than adults (>11 mm) (Brinton \& Wyllie 1976), we included both size classes to estimate the impact of the euphausiid assemblage on the anchovy population. Ignoring the smaller size class would have underestimated the predation impact.

\section{METHODS}

Field coliections. Field collections were made on 2 CalCOFI cruises: one in November 1986, prior to peak spawning of northern anchovy, aboard the RV 'New Horizon' and one in March 1987, during peak anchovy spawning, aboard the NOAA vessel 'David Starr

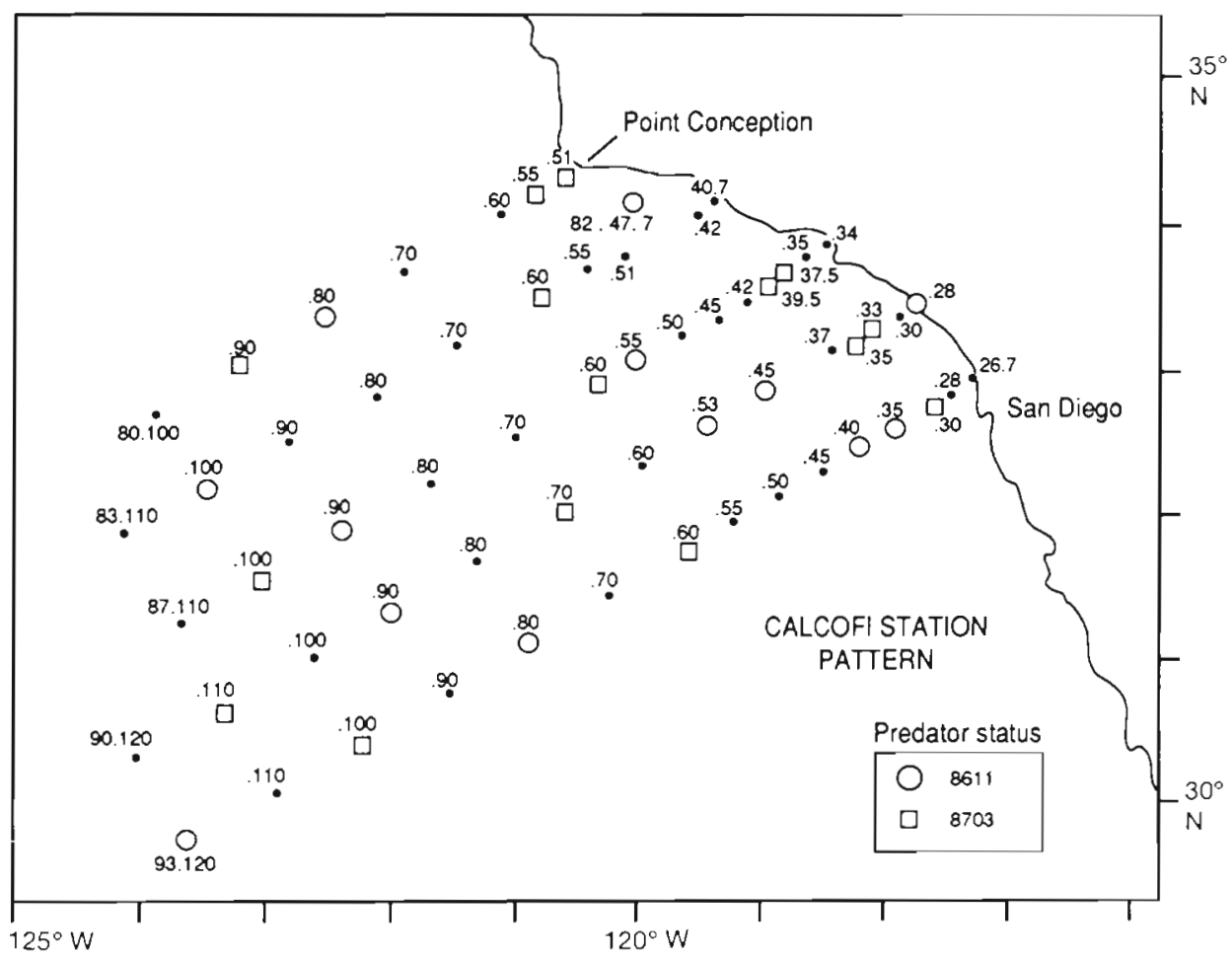

Fig. 1 Station pattern sampled by California Cooperative Oceanic Fisheries Investigations. Stations where separate collections were made for predators are indicated for November 1986 (CalCOFI Cruise 8611) and March 1987 (CalCOFI Cruise 8703)
Jordan'. We considered the November collections to be a control set. At each station (Fig 1), euphausiids and anchovy eggs and larvae were collected with standard double oblique plankton tows to $210 \mathrm{~m}$ using a Bongo net. Additionally, for the mortality estimates, anchovy eggs and larvae were collected with a CalVET (or PAIROVET) net lowered to a depth of $70 \mathrm{~m}$. Both Bongo and CalVET nets are paired cylindrical-conical nets. The Bongo net frame has $505 \mu \mathrm{m}$ mesh nets on both sides and the CalVET has 150 and $333 \mu \mathrm{m}$ mesh nets (Smith \& Richardson 1977, Smith et al. 1985). It was shown that there was no extrusion of eggs or larvae through the $150 \mu \mathrm{m}$ mesh (Lo 1983). The samples were preserved in $5 \%$ buffered formaldehyde.

Non-quantitative, oblique hauls to $50 \mathrm{~m}$ were taken. to collect euphausiids intended for immunoassays whenever the ship was on station (Fig. 1) between 22:00 and 02:00 h. The depth and time of haul were chosen because many euphausids migrate toward the sea surface at night (Brinton 1967) where they co-occur with eggs and yolk-sac larvae of northern anchovy which inhabit the upper $50 \mathrm{~m}$ of the sea (Ahlstrom 19.5.9). Additionally, feeding activity for Euphausia pacifica is maximal after sunset and during most of the night when they have moved into the surface layers (Willason \& Cox 1987). Euphausiids were collected using a black, $2 \mathrm{~mm}$ mesh Bongo net fitted with a plastic cod end. The dark net color should have decreased predator avoidance, and the large mesh should have allowed the prey to pass through the net, precluding potential biases caused by euphausiids feeding in the net (Nicol 1984). The plastic cod end was used to assure the retrieval of euphausiids in good condition. The large-mesh net selected for larger individuals.

Euphausiids were carefully transferred into buckets of surface seawater, 14 to $15^{\circ} \mathrm{C}$. (Ship's seawater was avoided, as it is often contaminated with metal ions.) Actively swimming euphausiids were selected, blotted quickly to remove excess seawater, and placed individually into 1.5 $\mathrm{ml}$ plastic tubes that were set in crushed ice. The sort- 
ing process took about $1 \mathrm{~min}^{\text {ind }}{ }^{-1}$ from bucket to cooled tube; after $10 \mathrm{~min}$, groups of tubes were frozen at $-80^{\circ} \mathrm{C}$.

Euphausiid abundance. In the laboratory, all preserved euphausiids were identified to the species level. These included the 6 most common species which were used in the immunological analyses and 10 additional species which were present and also considered to be possible predators. Subsampling and counting procedures are described in Brinton (1976). All specimens $\geq 6 \mathrm{~mm}$ were enumerated in 2 size groups, ( 6 to $11 \mathrm{~mm},>11 \mathrm{~mm}$ ), then their abundance was standardized to numbers under $10 \mathrm{~m}^{2}$ of water using the standard haul factor (Smith \& Richardson 1977). Earlier laboratory experiments with Euphausia pacifica showed that feeding rates differed between these 2 size groups (Theilacker \& Lasker 1974); euphausiids $<11 \mathrm{~mm}$ preyed on anchovy eggs and larvae at about one-third the rate of the larger size group.

The stations were divided into 2 categories for analysis. Category 1 included stations with a high euphausiid predation incidence, as determined by the immunoassay, and the other category included stations with a low predation incidence. Any station with predation incidence equal to or greater than the overall average was considered Category 1. Eleven stations from the March cruise were used in the analysis. Offshore stations (Stn numbers greater than 70) were excluded because they are beyond the geographic distribution of anchovy eggs and few yolk-sac larvae were found offshore in past surveys. An analysis of variance procedure was used to compare abundance data of euphausiids $>11 \mathrm{~mm}$ between the November and March cruises after the total abundance $>11 \mathrm{~mm}$ from each station was logarithm transformed.

Prey abundance and mortality rates. Anchovy eggs were counted, staged, and ages were assigned according to developmental rates (Lo 1985, Moser \& Ahlstrom 1985). Then eggs were grouped by half-day categories. Anchovy larvae were counted and measured. Stations used to determine prey abundance were the same stations used in euphausiid collections. Both eggs and yolk-sac larvae were used in the calculation of prey abundance. Standard length of net-collected and preserved yolk-sac larvae is $\leq 2.5 \mathrm{~mm}$.

Age-specific abundance of anchovy eggs collected from CalVET net tows and size-specific abundance of larvae $<9 \mathrm{~mm}$ from Bongo net tows were used in computing mortality rates. All stations occupied during the March 1987 cruise were used in this analysis. Preserved larval standard length was converted to live size (Theilacker 1980) and the age was estimated from a temperature-dependent Gompertz age-length growth curve (Methot \& Hewitt 1980, Lo 1983). The larval abundance data were adjusted to conform to the following standard conditions: no extrusion (Lo 1983) and a constant water volume filtered per unit depth (Smith \& Richardson 1977).

The abundance of larvae in each $1 \mathrm{~mm}$ length group was converted to daily production according to the following equation, assuming a steady state. For each station:

$$
P_{\mathrm{L}}=\frac{x(S H F / 10)(0.05)}{\left(R_{\mathrm{L})}(\% \text { Sort })\left(d r_{\mathrm{L}}\right)\left(a v_{\mathrm{L}}\right)\right.}
$$

where $P_{\mathrm{L}}=$ daily yolk-sac larval production per $0.05 \mathrm{~m}^{2}$ at average age $5 \mathrm{~d}$ from fertilization $(<2.75 \mathrm{~mm}) ; x=$ no. of $2.5 \mathrm{~mm}$ larvae; $S H F$ = standard haul factor, a factor used to convert catch of larvae to the no. of larvae under $10 \mathrm{~m}^{2}$ water (Smith \& Richardson 1977); $0.05\left(\mathrm{~m}^{2}\right)=$ sea surface area covered by the CalvET net; $R_{\mathrm{L}}=$ retention rate for length $L(\mathrm{~mm})$ anchovy larvae (Lo 1983); \% sort = percent of sample sorted by tow; $d r_{\mathrm{L}}(\mathrm{d})=$ average duration for each $1 \mathrm{~mm}$ length interval from 2.5 to $8.75 \mathrm{~mm}$; and $a v_{L}=$ the proportion of larvae that did not avoid the net.

Larval length was converted to age according to the procedures described in Lo $(1985,1986)$. The decrease in the daily abundance of eggs and larvae with age was considered to be their morality. A single-equation model was chosen to describe anchovy egg and larval mortality (Lo 1986):

$$
P_{l}=P_{0} \mathrm{e}^{-z x_{1}}\left(x_{2} / U\right)^{-\beta},
$$

where $P_{t}=$ daily egg or larval production per $0.05 \mathrm{~m}^{2}$ at age $t(\mathrm{~d}) ; P_{0}=$ daily egg production at age $0 ; z=$ daily instantaneous mortality rate for eggs and yolk-sac larvae; $x_{1}$ indexes eggs and larvae younger than age $U$ days, $x_{1}=t$ for $t<U, x_{1}=U$ for $t>U_{i} x_{2}$ indexes larvae older than age $U$ days, $x_{2}=U$ for $t<U, x_{2}=t$ for $t>U ; U$ $=$ age when the form of instantaneous mortality rate changes; $\beta=$ coefficient for the instantaneous mortality rate for larvae where the daily instantaneous mortality rate $=\beta / t, t>U$; and $t=\operatorname{age}(\mathrm{d})$.

Mortality rates of anchovy eggs and yolk-sac larvae were initially computed for the 2 high- and low-predation categories. Because of the few stations in each category ( 6 and 5 stations respectively), we could not detect a difference in total mortality between these 2 categories. In order to obtain a more precise and accurate overall mortality estimate, we used the abundance data for anchovy eggs and larvae $(<10 \mathrm{~mm})$ from the entire March cruise

Immunoassay. Aboard ship, a subsample (usually 6 to 10) of each night's euphausiid collection stored at $-80^{\circ} \mathrm{C}$ was assayed the following day. After the cruise, additional euphausiids were assayed at the Southwest Fisheries Science Center (SWFSC). Details of the immunoassay, a solid-phase enzyme-linked immunospot assay (ELISPOT) are given in Theilacker et al. (1986). 
Rabbits were immunized with anchovy yolk protein (the antigen) to prepare the primary, polyclonal antibody. Polyclonal antibodies were used to increase the likelihood of antibody binding to prey proteins that are partially degraded due to euphausiid proteolytic activity.

Only euphausiids $>11 \mathrm{~mm}$ were used in the assay. The stomach, hepatopancreas and hindgut were dissected out from the body and placed into $10 \mu \mathrm{l}$ of extraction buffer. Tissues were teased apart, and the extract was dotted onto $0.45 \mu \mathrm{m}$ pore nitrocellulose paper. The euphausiid gut contents on the nitrocellulose paper was reacted with the primary antibody. If the unknown gut contents contained anchovy yolk protein, it formed a complex with the primary antibody. The resulting antigen-antibody complex was treated with a secondary antibody which had been tagged with the enzyme alkaline phosphatase. The immobilized complex of antigen, primary antibody and secondary antibody on the nitrocellulose papor was visualized with a histochemical phosphatase stain; positive phosphatase activity produced a blue-black color (Theilacker et al. 1986).

In the ELISPOT, the color intensity of the reartion is directly related to the concentration of antigen (Ohman et al. 1991). However, in this situation, the concentration of antigen (yolk) did not correspond to the number of eggs or yolk-sac larvae eaten by the predator. The concentration of yolk ind. ${ }^{-1}$ is not a constant because as eggs and larvae develop, they utilize yolk and the quantity of yolk ind. ${ }^{-1}$ decreases. Thus, in our application, the immunoassay determines only the presence of yolk protein and not the number of eggs or larvae in the predator's gut.

Gut residence time and detection time. To estimate daily consumption by the euphausiid assemblage, information on the persistence of yolk protein in the guts of actively feeding individuals at in situ temperatures is required. The length of time a meal can be detected in a predator's gut using an immunoassay was designated the 'detection time' (Calver 1984, Sunderland 1988). In the SWFSC aquarium, we fed anchovy eggs to live Euphausia pacifica $>11 \mathrm{~mm}$ collected on the March cruise. In our tests, 20 eggs were fed to individual euphausiids in $500 \mathrm{ml}$ filtered seawater at $14{ }^{\circ} \mathrm{C}$. Because earlier experiments showed that E. pacifica ate an average of $1 \mathrm{egg}$ in $2 \mathrm{~h}$, the feeding treatment lasted $2 \mathrm{~h}$. The actual time of ingestion was unknown. After 1 or 2 eggs were eaten (determined by counting the remaining eggs), we either immediately froze the euphausiid for the 0-time sample or subsequently fed it algae (non-antibody reactive) and sampled at 30 or 60 min intervals for $6 \mathrm{~h}$. Algae was fed because earlier experiments showed that euphausiids retain their gut contents when feeding is interrupted (Lasker 1966, Willason \& Cox 1987).
The percent of tested euphausiids exhibiting a positive reaction to anchovy yolk protein was expected to decrease with time. The difference in \% positives between 2 points $\left(t_{1}\right.$ and $\left.t_{2}\right)$ provides an estimate of the proportion of euphausiids whose detection time $=t_{2}$. If the decrease in \% positive is linear, the loss rate per unit time is a constant (slope of the line), and the time corresponding to the $50 \%$ positive is the average detection time. We assayed individual euphausiids using the ELISPOT procedure to determine the average detection time for actively foraging Euphausia pacifica $>11 \mathrm{~mm}$. We ascribed the average detection time to the $>11 \mathrm{~mm}$ size category of all species analyzed in this study to compute hourly predation rates.

We have no data on detection time for 6 to $11 \mathrm{~mm}$ euphausiids. Ross (1982) found that allometric equations best described the relation between Euphausia pacifica body weight and rates of ingestion, respiration, excretion, growth and molting, thus revealing that all weight-specific physiological rates decreased with the increasing weight of the euphausiid. Because we could find no values in the literature to allow for a better assumption, we assumed that the fractional difference in the rate of digestion between 6 to $11 \mathrm{~mm}$ euphausiids and $>11 \mathrm{~mm}$ euphausiids was similar to the fractional difference in feeding rate. Thus, we inferred that the loss rate for yolk protein in 6 to $11 \mathrm{~mm}$ euphausiid guts was one-third the loss rate for $>11 \mathrm{~mm}$ individuals, and we divided the slope of the equation describing E. pacifica gut residence time by 3 to estimate the average detection time for the 6 to $11 \mathrm{~mm}$ euphausiid assemblage.

Predation rate. Daily euphausiid predation was estimated by considering the fraction of the euphausiid population by species that migrate into the depths inhabited by anchovy and the duration that they $\mathrm{co}-$ occur in the upper waters. Then the abundance of each euphausiid species by size was multiplied by the species-specific daily ingestion.

Among the euphausiids we sampled, vertical distribution is best known for Euphausia pacifica. E. pacifica has a daily depth range of 0 to $600 \mathrm{~m}$. Juveniles and adults occupy a daytime depth of 300 to $600 \mathrm{~m}$ (Brinton \& Wyllie 1976), but reach the upper $50 \mathrm{~m}$ at night (Brinton 1967). Brinton (1976) determined that $87 \%$ of E. pacifica $>6 \mathrm{~mm}$ reached the upper $50 \mathrm{~m}$ at night. Night was considered $1 \mathrm{~h}$ after sunset to $1 \mathrm{~h}$ before sunrise; total duration was ca $10 \mathrm{~h}$ in March. Thus to calculate predation rate we multiplied the total number of E. pacifica under $10 \mathrm{~m}^{2}$ by 0.87 . Abundances of the other euphausiids present in the study were similarly adjusted (Table 1).

Species-specific daily ingestion was determined by considering the results of the immunoassay. Because the immunoassay only determined the presence or 
Table 1. Day and night vertical range of euphausiid species ${ }^{\star}$

\begin{tabular}{|c|c|c|c|}
\hline Species & $\begin{array}{l}\text { Vertical } \\
\text { range }\end{array}$ & $\begin{array}{c}\% \text { Population } \\
\text { upper } 50 \mathrm{~m} \\
6-11 \mathrm{~mm}\end{array}$ & $\begin{array}{l}\text { reaching } \\
\text { at night } \\
>11.5 \mathrm{~mm}\end{array}$ \\
\hline $\begin{array}{c}\text { Euphausia } \\
\text { pacifica }\end{array}$ & $0-600 \mathrm{~m}$ & 87 & 87 \\
\hline E. gibboides ${ }^{b}$ & $0-600 \mathrm{~m}$ & 87 & 87 \\
\hline E. eximía & $0-600 \mathrm{~m}$ & 87 & 87 \\
\hline E. recurva & $0-600 \mathrm{~m}$ & 87 & 87 \\
\hline E. mutica & $0-600 \mathrm{~m}$ & 87 & 87 \\
\hline E. hemigibba & $0-600 \mathrm{~m}$ & 87 & 87 \\
\hline $\begin{array}{l}\text { Nematoscelis } \\
\text { difficilis }\end{array}$ & $\begin{array}{l}\text { Thermocline to } \\
\text { ca } 300-600 \mathrm{~m}\end{array}$ & 70 & 40 \\
\hline N. atlantica & $\begin{array}{l}\text { Thermocline to } \\
\text { ca } 300-600 \mathrm{~m}\end{array}$ & 70 & 40 \\
\hline N. tenella & $\begin{array}{l}\text { Thermocline to } \\
\text { ca } 300-600 \mathrm{~m}\end{array}$ & 70 & 40 \\
\hline $\begin{array}{c}\text { Thysanoessa } \\
\text { gregaria }\end{array}$ & $0-150 \mathrm{~m}^{\mathrm{r}}$ & 60 & 60 \\
\hline$T$ spinifera & $0-100 \mathrm{~m}^{\mathrm{r}}$ & 87 & 87 \\
\hline $\begin{array}{l}\text { Thysanopoda } \\
\text { astylata }\end{array}$ & $0-600 \mathrm{~m}$ & 87 & 87 \\
\hline $\begin{array}{c}\text { Stylocherion } \\
\text { carinatum }\end{array}$ & $0-150 \mathrm{~m}$ & 87 & 87 \\
\hline S. affine & $0-200 \mathrm{~m}^{\mathrm{c}}$ & 87 & 87 \\
\hline $\begin{array}{l}\text { Nictiphanes } \\
\text { simplex }\end{array}$ & $0-150 \mathrm{~m}$ & 87 & 87 \\
\hline \multicolumn{4}{|c|}{ 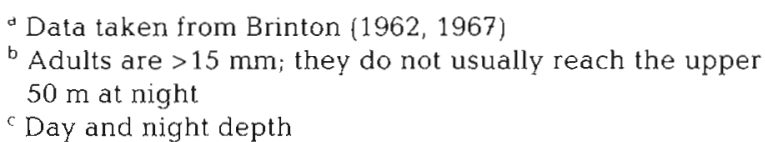 } \\
\hline
\end{tabular}

absence of yolk protein in euphausiid guts, a Poisson distribution was used to describe the mean no. of prey ingested over an interval of time defined by the duration of gut passage, or the detection time. This distribution assumes that ingestion events were independent and randomly distributed over each time interval. Accordingly, the frequency of negative assays can be related to the number of ingestion events by

$$
P(x=0)=e^{-\mu}
$$

where $P(x=0)=$ the probability of no anchovy being eaten (negative immunoassays) and $\mu=$ mean no. of prey ingested per time interval. That is, we equated the relative frequency of zero predation to the $\exp (-$ mean $)$ and solved for the mean no. of eggs and yolk-sac larvae eaten by 1 euphausiid. The mean number eaten $\mathrm{h}^{-1}$ was estimated by dividing by the laboratory-determined detection time. Ingestion by 6 to $11 \mathrm{~mm}$ euphausiids was assumed to be the same as Euphausia pacifica of that size and was multiplied by 0.3 to account for their slower feeding rate (Theilacker \& Lasker 1974, Ross 1982). Detection time for the 6 to $11 \mathrm{~mm}$ group was adjusted as discussed above.

Here a negative assay provides more information than a positive one. A negative assay indicates that the euphausiid predator has not eaten during the measured detection time. A positive assay indicates that the euphausiid has eaten 1 or more prey; there is no temporal information.

To estimate the impact of the euphausid population preying on the anchovy population, we compared the loss of anchovy with the total natural egg and larval mortality that was determined independently.

\section{RESULTS}

\section{Field collections}

On the November cruise in 1986, plankton collections were taken at 58 stations. At 13 stations, tows for invertebrate predators were also made (Fig. 1). Only 1 of the predator collections was taken inshore where some anchovy spawning had occurred (Fig. 2a).

On the March cruise in 1987, plankton collections were taken at 57 stations. Fifteen invertebrate tows were taken (Fig. 1), and 10 of them corresponded to areas where anchovy eggs and yolk-sac larvae were collected. In 1987, anchovy spawning was moderate in the Southern California Bight (Fig. 2b).

\section{Euphausiid abundance}

The mean abundance of adult euphausiids $>11.0 \mathrm{~mm}$, all species combined, was similar between the November (346.5 ind. per $10 \mathrm{~m}^{2}$ ) and March (287.9 ind. per $\left.10 \mathrm{~m}^{2}\right)$ cruises $(F=0.33 ; \mathrm{df}=1,23 ; \mathrm{p}=0.57 ; F$ test computed on log-transformed data). The abundance under $10 \mathrm{~m}^{2}$ at 12 stations in November ( $\mathrm{n}=12$ ) ranged from 18 to 1074 adults, and in March $(n=13)$ abundance ranged from 41 to 1352 adults. The highabundance, nearshore ( $<60$ mile) stations were dominated by Euphausia pacifica and Nematoscelis difficilis in November and March (Tables $2 \& 3$ ).

Five euphausiid species dominated the assemblage in March; these species were analyzed for evidence of predation and their abundance is detailed here together with information on depth distribution (Table 1) and relative abundance (Brinton 1967, Brinton \& Wyllie 1976). A sixth euphausiid species, Nyctiphanes simplex, was analyzed for 1 station only (87.39.5; Table 3 ).

Euphausia pacifica, usually the most common species in the southern California area, was present at 9 of the 10 stations used in the predation analysis for the March cruise and was dominant at 5 of the 10 stations.

Nematoscelis difficilis is usually second in abundance among the euphausiids in the southern California area. It migrates through a vertical range of about $300 \mathrm{~m}$. The 2 size groups of $N$. difficilis were 

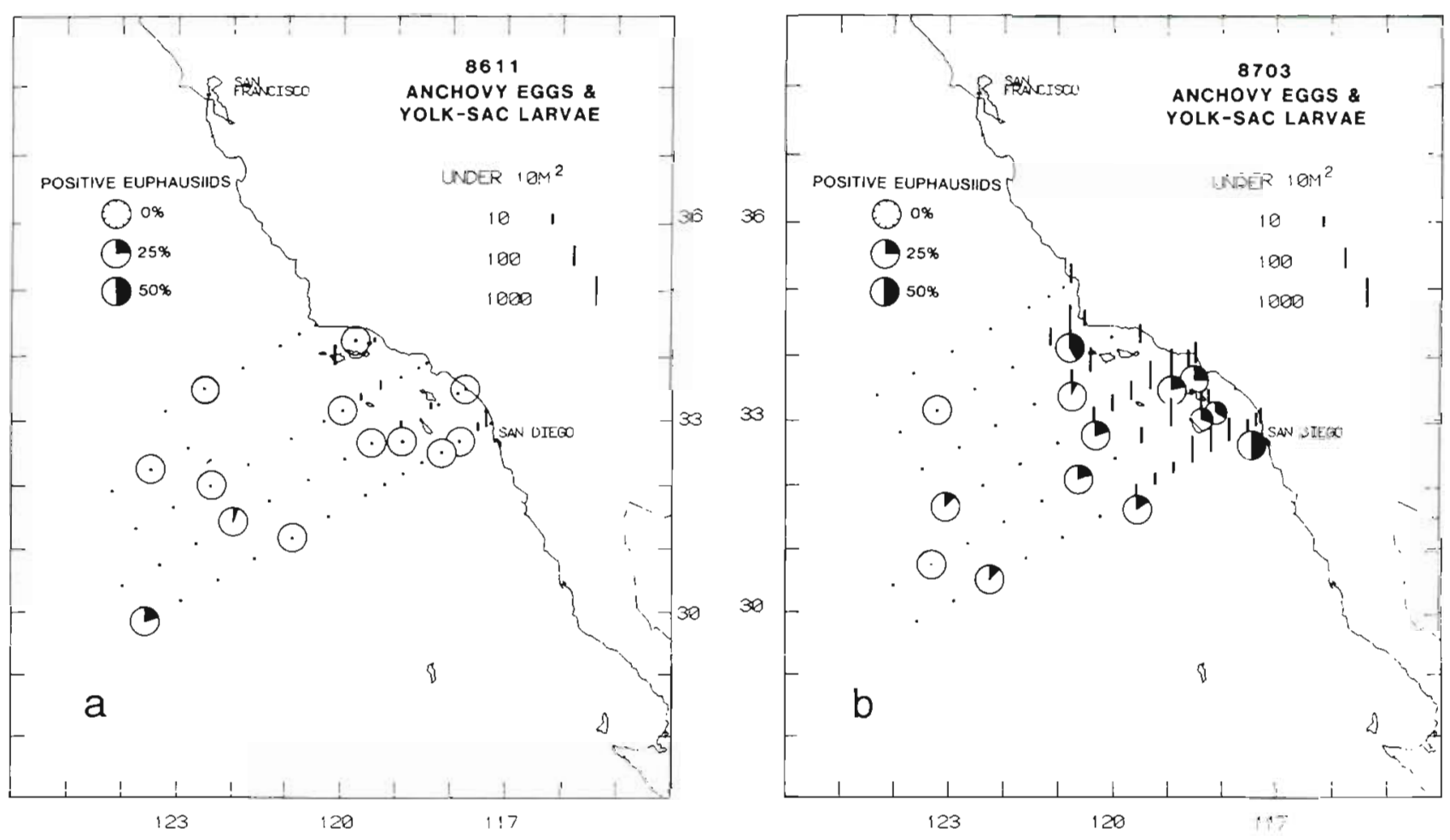

Fig. 2. Engraulis mordax. Distribution of positive euphausiid predators, expressed as \% positive, superimposed on northern anchovy egg and yolk-sac larval abundance for (a) November 1986 and (b) March 1987. Anchovy numbers adjusted to equal the average abundance under $10 \mathrm{~m}^{2}$ of sea surface

dominant at Stns 87.35 and 93.30 and present at all 10 stations.

Euphausia gibboides migrates from a depth of 300 to $500 \mathrm{~m}$ in the daytime to the thermocline at night. It was present at 9 of the 10 stations in the study area. Like Euphausia recurva, it occurred more offshore than $E$. pacifica, but their distribution overlapped. The highest abundance was at Stn 93.60 with both size groups equal in number. E. gibboides adults would not be expected to reach the upper $50 \mathrm{~m}$ at night unless the thermocline was particularly shallow, therefore individuals $>15.5 \mathrm{~mm}$ were not used in the predation estimate.

Euphausia eximia was present in 5 of the 10 stations in this study, with its highest abundance at Stn 83.60. All developmental stages of E. eximia are concentrated in the surface layer at night.

Euphausia recurva migrates from $300-600 \mathrm{~m}$ to $0-100 \mathrm{~m}$ at night. It was present at 6 of the 10 stations in this study, reaching its highest abundance at Stn 93.60 with a total of 425 ind. per $10 \mathrm{~m}^{2}$ for the $>11.5 \mathrm{~mm}$ group

Nyctiphanes simplex migrates from $150 \mathrm{~m}$ to the surface at night. It was present at 8 of the 10 study stations, and its highest abundances were at Stns 93.30 and 87.39 .5 .

\section{Prey abundance and mortality rate}

The presence of anchovy prey was minimal in November and abundant in March, with most of the spawning occurring in the Southern California Bight (Fig. 2a, b). In November, anchovy eggs were found at only 1 predator station (36 eggs per $10 \mathrm{~m}^{2}$ at Stn 90.45), whereas in March, abundant eggs and yolk-sac larvae were collected at the nearshore predator stations (Table 4).

Mortality rates for the March cruise were determined using Eq. 2, assuming that eggs and yolk-sac larvae (younger than $5 \mathrm{~d}$ ) follow an exponential decay $(z=0.036, \mathrm{SE}=0.036)$ and older larvae follow a Peratotype of instantaneous mortality $(B=1.989, \mathrm{SE}=0.213)$ (Table 5). $P_{0}=4.13$ eggs per $0.05 \mathrm{~m}^{2}(\mathrm{SE}=0.67$ ) for the entire survey area. The $z$-value of 0.036 was later used as the daily mortality rate for both high-and low-predation categories described in the 'Methods' section.

\section{Euphausiid predation}

On the November cruise, only 1 euphausiid collection station (90.45) was taken near shore where there was some anchovy spawning (Fig. 2a). In all, 119 eu- 
Table 2. Mean abundance of the dominant euphausiid species under $10 \mathrm{~m}^{2}$ of sea surface taken at stations where predator collections were made in November 1986. $95 \%$ confidence intervals obtained from $\log _{10}$ transformation are in parentheses

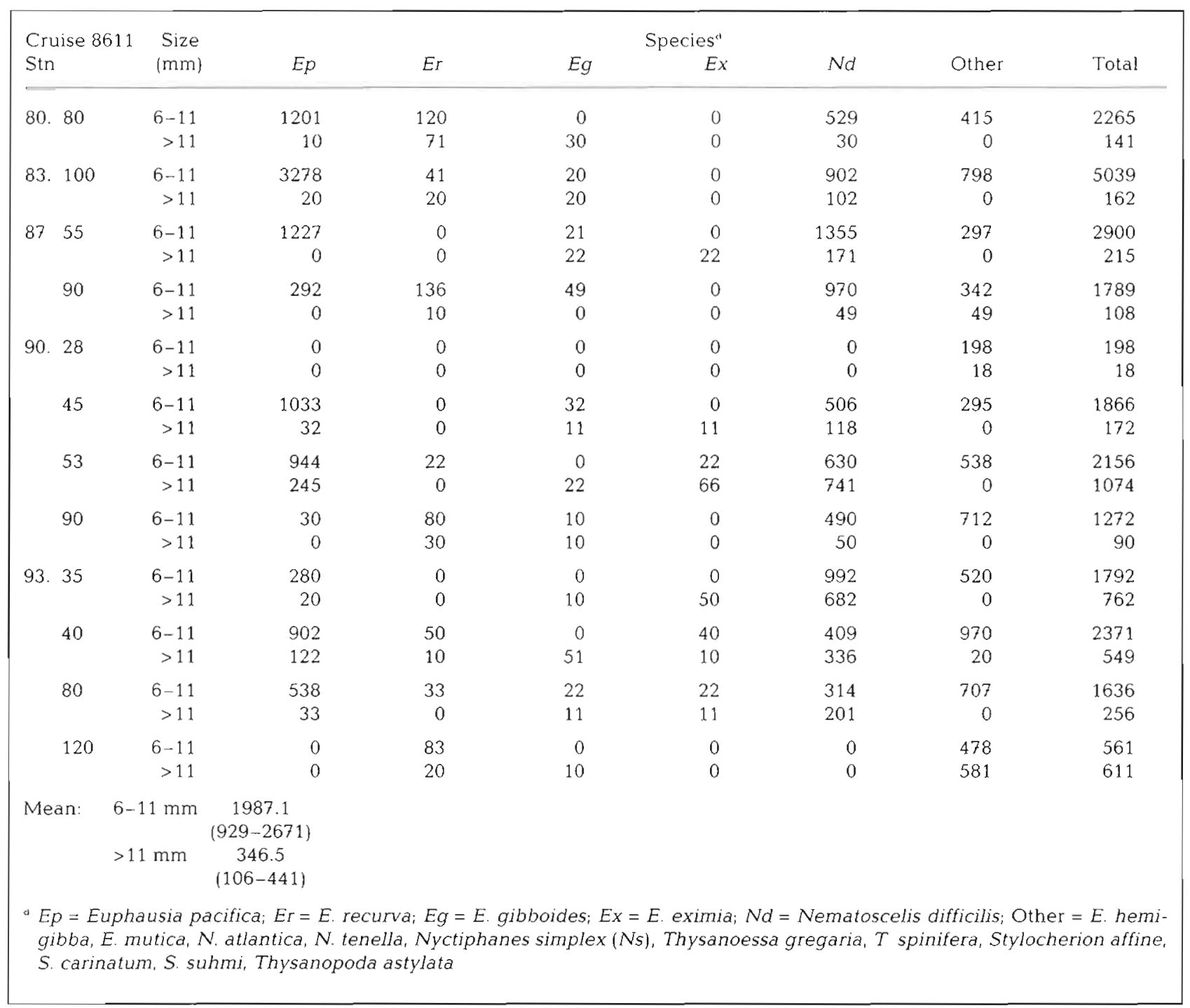

phausiids were assayed and 2 individuals tested positive for anchovy remains. The 2 positive-reactive euphausiids, both Euphausia gibboides, were collected at 2 stations 250 to 350 mile offshore where no eggs or larvae were collected (Fig. 2a).

On the March cruise, predator samples were taken at 10 stations where anchovy eggs and yolk-sac larvae were collected. Between 9 and $50 \%$ of the predatory euphausiids at these stations tested positive (Table 6). In all, 67 or $24 \%$ of the 283 euphausiids assayed tested positive for anchovy yolk protein. Although the relation between percent positive euphausiids and prey abundance was variable at low prey levels, the number of euphausiids eating anchovy seemed to increase rapidly with a small increase in prey abundance (Fig. 3).
Maximum percent feeding appeared to be above 1000 prey under $10 \mathrm{~m}^{2}$. Again, as in the November cruise, a few positive-reactive euphausiids (Euphausia recurva) were taken from offshore stations outside the anchovy spawning area (Table 6, Fig. 2b).

\section{Gut residence time and detection time}

Results from the digestion experiments showed that yolk protein, consumed by eating 1 or 2 anchovy eggs, could not be detected in the guts of actively foraging euphausiids after $6 \mathrm{~h}$ (Fig. 4). The decrease in the percentage of positive euphausiids appeared to be linear with time; an exponential description of the data was 
Table 3. Abundance of the dominant euphausiid species under $10 \mathrm{~m}^{2}$ of sea surface taken at stations where predator collections were made in March $198795 \%$ confidence intervals obtained from $\log _{10}$ transformation are in parentheses. Species abbreviations as in Table 2

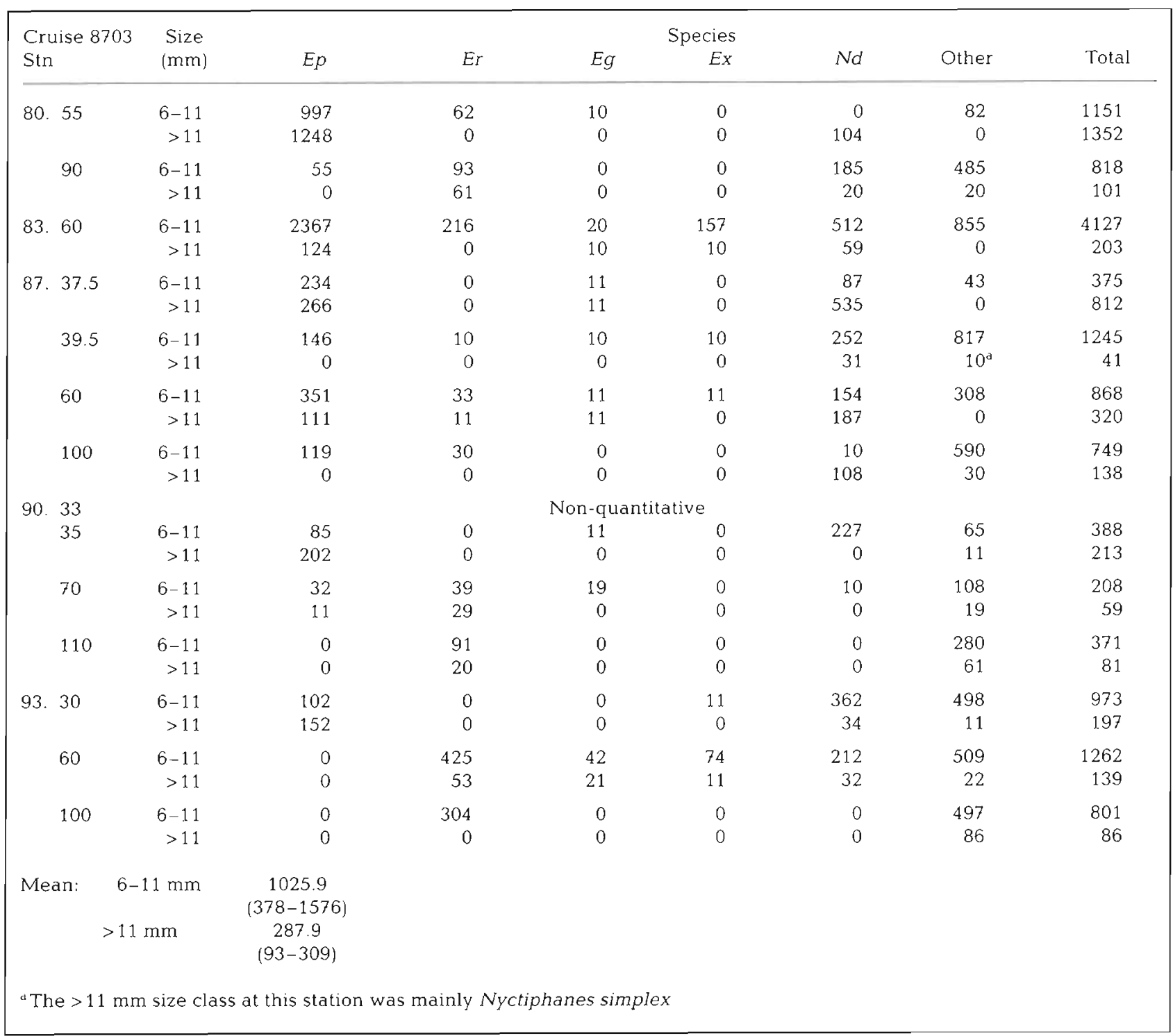

poor. The weighted linear regression predicted a loss rate of about $13 \% \mathrm{~h}^{-1}$ (slope), a detection time of $7,2 \mathrm{~h}$, and a $50 \%$ probability of complete digestion of the yolk protein after $3.5 \mathrm{~h}$.

\section{Euphausiid predation rate}

To set up a comparative analysis of prey mortality due to euphausiid predation, we used the computed predation incidence $(0.237$; Table 6$)$ as a guide for grouping the stations into 2 categories: an area of high predation $(\geq 0.24)$ and an area of low predation $(<0.24)$. Our hypothesis was that more prey will be eaten in the high-predation area. The high-predation category included the following 6 stations: 93.28, 93.30, 90.33, $90.35,87.37 .5$, and 80.55 . To have a sufficient number of eggs and larvae for the analysis of prey abundance in the high-predation area, we included Stn 93.28, which was very close to Stn 93.30. The low-predation category contained 5 stations: 93.60, 90.70, 87.39.5, 87.60, and 83.60. Stations in the high-predation category were closer to shore than those in the low-predation category (Fig. 1, Tables $4 \& 6$ ).

The potential predation impact by the euphausiid population was estimated by considering the abundance and feeding rate of each predatory species quantified in this study. The nearshore euphausiid spe- 
Table 4. Engraulis mordax. Abundance of northern anchovy eggs and yolk-sac larvae under $10 \mathrm{~m}^{2}$ of sea surface taken in Bongo net tows at stations where predator collections were made in March 1987

\begin{tabular}{|lrr|}
\hline $\begin{array}{l}\text { Cruise } 8703 \\
\text { Stn }\end{array}$ & $\begin{array}{c}\text { Anchovy } \\
\text { eggs }\end{array}$ & $\begin{array}{c}\text { Anchovy } \\
\text { yolk-sac } \\
\text { larvae }\end{array}$ \\
\hline 80.51 & 580 & 32 \\
55 & 39244 & 793 \\
90 & 0 & 0 \\
83.60 & 0 & 256 \\
87.37 .5 & 1259 & 13833 \\
39.5 & 24220 & 15487 \\
60 & 0 & 1568 \\
100 & 0 & 0 \\
90.33 & 877 & 7787 \\
35 & 1576 & 7200 \\
70 & 0 & 0 \\
110 & 0 & 0 \\
93.28 & 559 & 7835 \\
30 & 525 & 145 \\
60 & 0 & 389 \\
100 & 0 & 0 \\
Total & & 55325 \\
& 68840 &
\end{tabular}

Table 5. Daily production under $0.05 \mathrm{~m}^{2}\left(P_{1}\right)$ of anchovy eggs (E) and larvae at age $t$ from the March 1987 cruise. Eggs are from 40 stations and larvae are from 46 stations. See 'Methods' for $x_{1}$ and $x_{2} . P_{t}$ were computed for the entire survey area in Fig. 1 The inverse of MSE was used as case weight for a weighted nonlinear regression

\begin{tabular}{|lrcccc|}
\hline $\begin{array}{l}\text { Egg or } \\
\text { larvae }(\mathrm{mm})\end{array}$ & $\begin{array}{c}t \\
(\mathrm{~d})\end{array}$ & $P t$ & $x_{1}$ & $x_{2}$ & MSE \\
\hline $\mathrm{E}$ & 0.38 & 3.945 & 0.38 & 5 & 1.1394 \\
$\mathrm{E}$ & 0.83 & 3.262 & 0.83 & 5 & 1.1394 \\
$\mathrm{E}$ & 1.39 & 3.909 & 1.39 & 5 & 1.1394 \\
$\mathrm{E}$ & 1.85 & 4.320 & 1.85 & 5 & 1.1394 \\
$\mathrm{E}$ & 2.40 & 5.590 & 2.40 & 5 & 1.1394 \\
$\mathrm{E}$ & 2.80 & 2.800 & 2.80 & 5 & 1.1394 \\
& & & & & \\
$2.0-3.0$ & 4.87 & 3.570 & 5 & 4.87 & 0.049 \\
$3.5-4.0$ & 8.54 & 1.595 & 5 & 8.54 & 0.049 \\
$4.5-5.0$ & 11.27 & 0.502 & 5 & 11.27 & 0.049 \\
$5.5-6.0$ & 13.65 & 0.311 & 5 & 13.65 & 0.049 \\
$6.5-7.0$ & 15.88 & 0.236 & 5 & 15.88 & 0.049 \\
$7.5-8.0$ & 18.14 & 0.147 & 5 & 18.14 & 0.049 \\
$8.5-9.0$ & 20.34 & 0.153 & 5 & 20.34 & 0.049 \\
\hline
\end{tabular}

cies ate 2291 anchovy eggs and yolk-sac larvae $\mathrm{d}^{-1}$ per $10 \mathrm{~m}^{2}$, roughly 3 times the number of prey eaten daily by the offshore euphausiids (Table 7). No variances for these estimates were obtained. At these feeding rates, the euphausiid assemblage ate ca $2.8 \%$ of the anchovy population $\mathrm{d}^{-1}$ in the nearshore area and $1.7 \% \mathrm{~d}^{-1}$ in

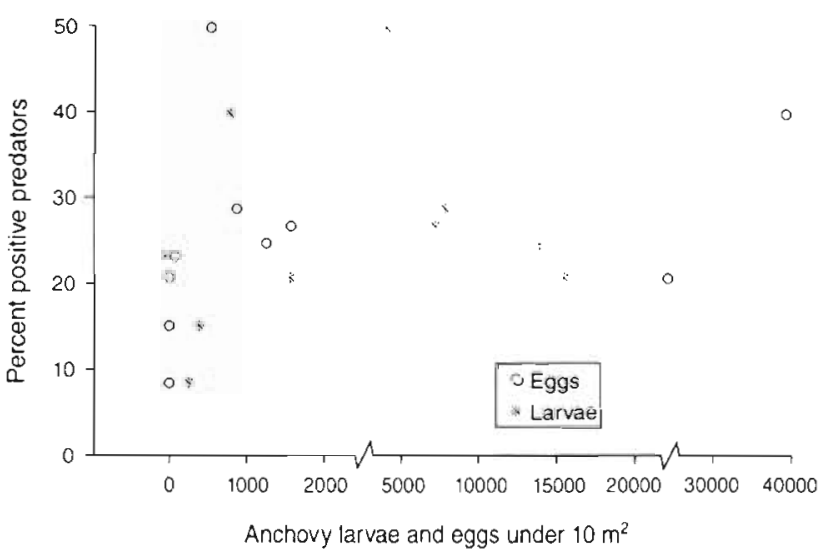

Fig. 3. Engraulis mordax. Scatter diagram of abundance of northern anchovy eggs and yolk-sac larvae and the positivereactive euphausiid predators at concurrent stations in March 1987

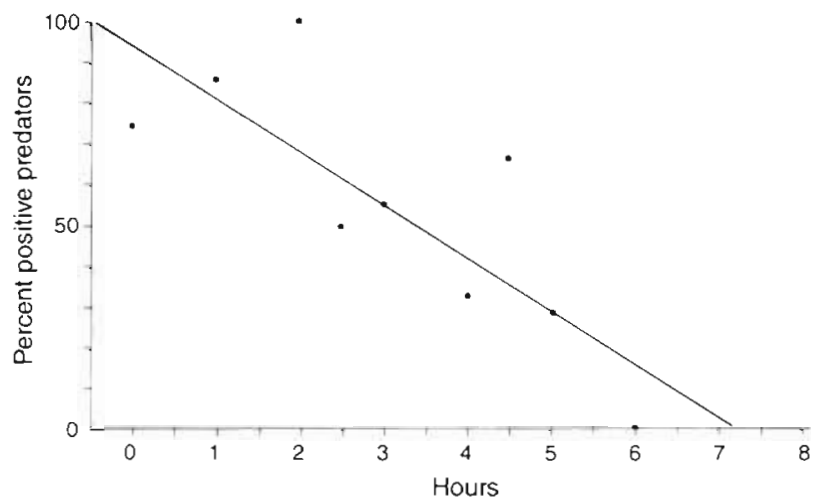

\begin{tabular}{|c|c|c|}
\hline $\begin{array}{c}\text { HOURS } \\
\text { FED ALGAE }\end{array}$ & $\begin{array}{c}\text { ELISPOT } \\
\text { (fraction+) }\end{array}$ & $\begin{array}{l}\text { ELISPOT } \\
\text { (percent+) }\end{array}$ \\
\hline 0 & $6 / 8$ & 75 \\
\hline 1 & $6 / 7$ & 86 \\
\hline 2 & 77 & 100 \\
\hline 2.5 & $1 / 2$ & 50 \\
\hline 3 & $5 / 9$ & 56 \\
\hline 4 & $2 / 6$ & 33 \\
\hline 4.5 & $2 / 3$ & 66 \\
\hline 5 & 27 & 29 \\
\hline 6 & $0 / 6$ & 0 \\
\hline
\end{tabular}

Fig. 4. Euphausia pacifica, Engraulis mordax. Percent of actively foraging $E$. pacifica that have anchovy yolk protein in their guts ( $p$, percent positive; no. positive/no. tested) as a function of hours since feeding ( $t$, in hours): $p=94.6-12.7 t$

the offshore area (Table 7 ). This rate of predation accounts for between 47 and $78 \%(0.017 / 0.036=0.47$; $0.028 / 0.036=0.78$ ) of the anchovy natural mortality (Table 7)

\section{DISCUSSION}

The ELISPOT immunoassay confirmed that predation by euphausiids was a significant source of mortality for the young stages of northern anchovy off California. Anchovy prey may be extremely vulnerable to euphausiids, for the pelagic eggs are spawned 
Table 6. Predator stations in March 1987 and frequencies of positive immunoassay reactions (no. positive/no. examined) by species. Species abbreviations as in Table 2

\begin{tabular}{|c|c|c|c|c|c|c|c|c|c|}
\hline $\begin{array}{l}\text { Cruise } 8703 \\
\text { Stn }\end{array}$ & $E p$ & Er & $E g$ & $\begin{array}{r}\text { Species } \\
E x\end{array}$ & $N d$ & Ns & Other & $\begin{array}{l}\text { Positive } \\
\text { fraction }\end{array}$ & $\begin{array}{l}\text { Total \% } \\
\text { positive }\end{array}$ \\
\hline 81.55 & $8 / 19$ & - & - & - & $0 / 1$ & - & - & $8 / 20$ & 40.0 \\
\hline 90 & $0 / 1$ & $0 / 2$ & - & $0 / 3$ & - & - & - & $0 / 6$ & 0 \\
\hline 83. 60 & $2 / 20$ & - & - & $0 / 1$ & $0 / 2$ & - & - & $2 / 23$ & 8.7 \\
\hline 87. 37.5 & $4 / 17$ & - & $1 / 2$ & - & $0 / 1$ & _- & - & $5 / 20$ & 25.0 \\
\hline 39.5 & - & - & - & - & $0 / 1$ & $4 / 18$ & - & $4 / 19$ & 21.1 \\
\hline 60 & $1 / 7$ & $0 / 1$ & $2 / 4$ & $0 / 1$ & $1 / 5$ & - & $0 / 1$ & $4 / 19$ & 21.1 \\
\hline 100 & - & $3 / 9$ & $0 / 4$ & - & $0 / 7$ & - & - & $3 / 20$ & 15.0 \\
\hline 90.33 & $6 / 19$ & - & - & - & $0 / 1$ & - & $1 / 4$ & $7 / 24$ & 29.2 \\
\hline 35 & $7 / 25$ & - & - & - & - & - & $0 / 1$ & $7 / 26$ & 26.9 \\
\hline 70 & - & $4 / 15$ & $0 / 2$ & - & - & - & - & $4 / 17$ & 23.5 \\
\hline 110 & - & $0 / 15$ & $0 / 1$ & - & - & _- & - & $0 / 16$ & 0 \\
\hline 93. 30 & $17 / 34$ & - & - & - & $1 / 2$ & - & - & $18 / 36$ & 50.0 \\
\hline 60 & - & $0 / 9$ & $1 / 2$ & $1 / 1$ & $0 / 1$ & - & - & $2 / 13$ & 15.4 \\
\hline 100 & - & $3 / 24$ & - & - & & - & - & $3 / 24$ & 12.5 \\
\hline Total & $45 / 142$ & $10 / 75$ & $4 / 15$ & $1 / 6$ & $2 / 21$ & $4 / 18$ & $1 / 6$ & $67 / 283$ & 23.7 \\
\hline$\%$ Positive & 31.7 & 13.3 & 26.7 & 16.7 & 9.5 & 22.2 & 16.7 & & \\
\hline
\end{tabular}

in a large patch and in an area of high euphausiid concentration at night when the euphausiids rise to the surface. McGurk (1986) has suggested that the patchy distribution of fish eggs and larvae may result in high mortality rates due to predation. During this study between 47 and $78 \%$ of the natural mortality could be ascribed to euphausiid predation. It is reasonable to suggest that predation, and not starvation, was the main source of early mortality since eggs and early larvae are not dependent on exogenous foods.

To analyze our data, we stratified the stations according to predation rate. The population abundance of euphausiids was quantified over the area of cooccurrence with anchovy. Our hypothesis was that more prey will be eaten in areas where the incidence of predation was high. Calculated predation rates that relied on direct evidence of predator gut contents, prey and predator co-occurrence, prey and predator abundance estimates, and predator digestive capacities indicated that the fraction of the anchovy population removed by the euphausiid population was greater nearshore $(0.028)$ than offshore $(0.017)$. Thus euphausiid feeding rate seemed to depend on encounter rate resulting in higher predation nearshore where prey were more abundant. Euphausia pacifica dominated the nearshore stations and had the highest ( $37 \%$ ) incidence of predation. An earlier feasibility study had a similar outcome (Theilacker 1988). The incidence of predation by E. pacifica detected using ELISPOT was greater $(79 \%)$ at a single nearshore station where anchovy densities were higher than at an offshore station $(8 \%)$ where anchovy densities were low.

A more meaningful, physiological approach to establishing differences between stations would be to strat- ify by prey abundance using the prey levels above and below the critical prey level for maximum feeding rate as portrayed by a functional response curve (Peterman \& Gatto 1987). Although we do not have sufficient data to determine this level, the general shape of the relation described in Fig. 3 suggests that the maximum percent feeding by euphausiids occurred at prey concentrations of ca 1000 prey per $10 \mathrm{~m}^{2}$. The relation between euphausiid predation and prey abundance appeared to increase rapidly with a small increase in prey level (Fig. 3). In our study, the cutoff used for the high and low predation areas ( $24 \%$ positive predators) corresponded to what appears to be the critical prey concentration (Fig. 3), lending additional credence to the areas selected for comparison. Additionally, little predation was observed in November 1986 (Fig. 2a) when the maximum prey concentration was 100 per $10 \mathrm{~m}^{2}$

Although laboratory data on the predatory behavior of some of the assemblage euphausiids is not available, it is clear on grounds of functional morphology as well as experimental evidence and gut content studies, that the relative importance of plant and animal prey differs in euphausiid species (Mauchline 1967). Most euphausiids are omnivorous (Ohman 1984, McClatchie 1985). Stuart (1986) found in the laboratory that adult ( $\geq 11 \mathrm{~mm}$ ) Euphausia lucens were able to consume large numbers of anchovy larvae. E. lucens also consumes phytoplankton and copepods (Stuart \& Pillar 1990). Theilacker \& Lasker (1974) showed in laboratory experiments that the median number of yolksac anchovy larvae eaten ind.$^{-1} \mathrm{~d}^{-1}$ by $E$. pacifica ranged from 2 to 17: larval $(<6 \mathrm{~mm})$ E. pacifica ate 2, juveniles ( 6 to $11 \mathrm{~mm}$ ) ate 6 , and adults $(>11 \mathrm{~mm})$ ate 
17. In this study, 6 species tested from the field had eaten anchovy. In the laboratory, euphausiids were capable of consuming enough anchovy prey to meet their daily metabolic requirements (E. pacifica, Theilacker \& Lasker 1974; E. lucens, Stuart 1986). But for E. pacifica $<11 \mathrm{~mm}$, there appears to be a point of satiation. Offered abundant prey, juvenile E. pacifica seldom ate more than 6 larvae $d^{-1}$ (Theilacker \& Lasker 1974).
Therefore our estimates of 0.1 to 2 anchovy consumed $\mathrm{d}^{-1}$ ind. $^{-1}$ seem reasonable considering that they would also be consuming other prey. Likewise, measured phytoplankton ingestion rates of E. pacifica studied in the field were low, probably because they were consuming other foods in addition to phytoplankton (Willason \& Cox 1987).

Euphausiids are numerically one of the major plank-

Table 7. Comparison between the high- and low-predation stations of euphausiid species-specific feeding rates, the impact of euphausiid predation on the anchovy population, and total anchovy natural mortality rates

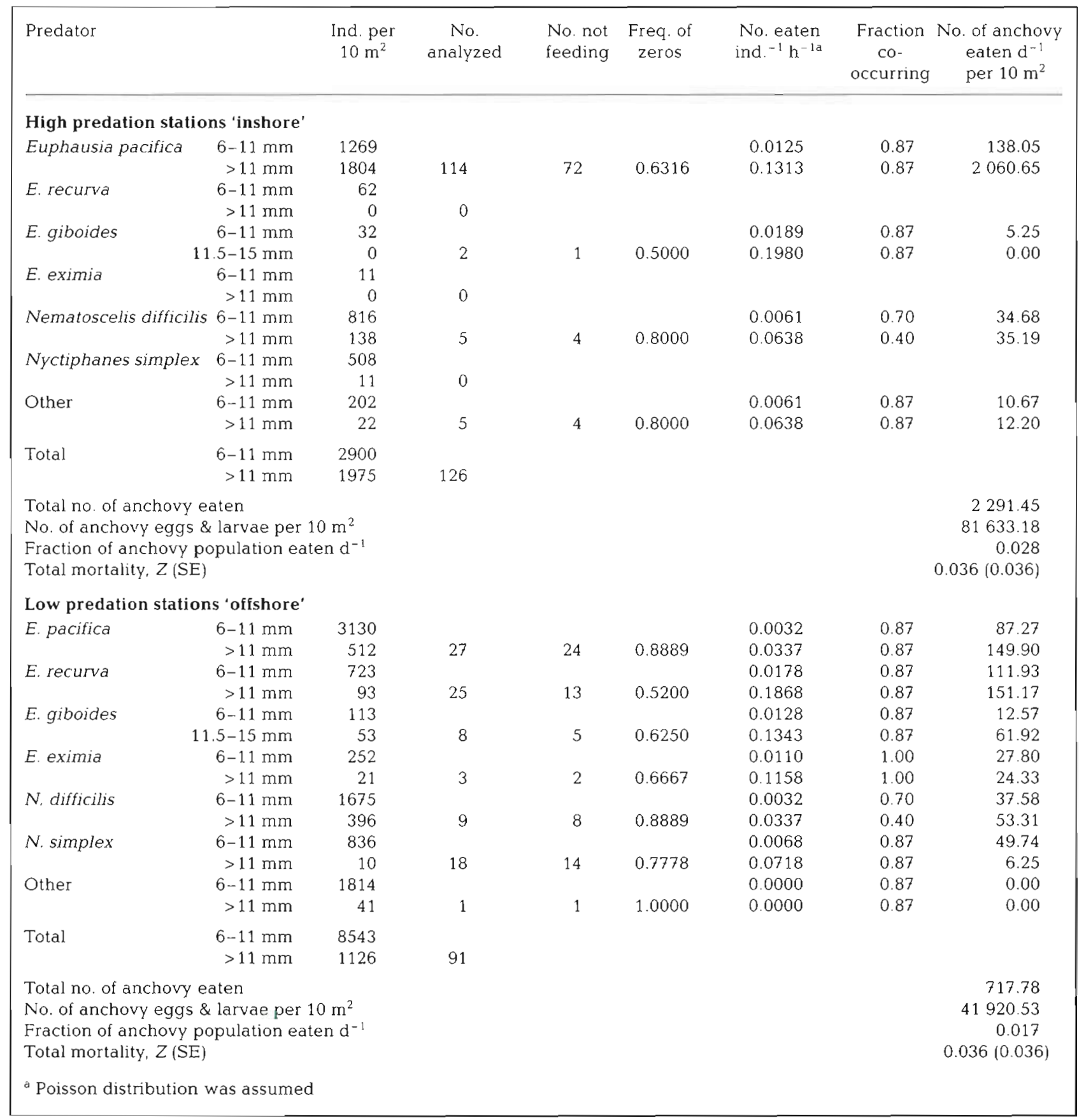


tonic organisms in the eastern north Pacific (Boden et al. 1955). They co-occur with the eggs and larvae of pelagic spawning fishes. The euphausiid abundances that we calculated are averages. At times, abundances of euphausiids are extremely high. Surface swarms of Thysanoessa spinifera are common events off California during spring and summer (Smith \& Adams 1988). There are numerous theories, including congregating to feed, about the mechanisms that cause swarming, but Smith \& Adams (1988) argue that it is mainly related to reproduction. Likewise, Endo et al. (1985) concluded that E. pacifica in Sendai Bay, Japan, swarmed for reasons other than feeding (e.g. possibly mating). On the other hand, Brown et al. (1979, in McClatchie 1985) note that swarms of Meganyctiphanes norvegica in the Bay of Fundy preyed on copepods. Stimuli for swarming are complex and probably vary (Komaki 1967, Antezana et al. 1972). However, the tendency for euphausids to concentrate near the surface during swarming could contribute importantly to variability in predation mortality of anchovy larvae.

In addition to euphausiids preying on the young stages of fish, other carnivorous invertebrates in the California Current also may eat fish eggs and larvae. The biomass of calanoid copepods appears to be about 3 times that of euphausiids (Isaacs et al. 1969). In laboratory experiments, some predatory copepods can consume as many fish larvae $\mathrm{d}^{-1}$ as euphausiids (Hunter 1984, Bailey \& Houde 1989); however, unlike euphausiids (Theilacker \& Lasker 1974), copepod feeding rate is reduced in the presence of an alternate prey (Lillelund \& Lasker 1971, Bailey \& Yen 1983). Thus, it is reasonable to expect euphausiids to continue to feed on larvae when they are available.

In the field, gelatinous invertebrates are considered significant predators on both eggs and larvae (Moller 1984, Purcell 1985, 1989, 1990). De Lafontaine \& Leggett (1988) consider jellyfish predation to be the primary cause of mortality of larval capelin Mallotus villosus. In the California Current, jellyfish are not a significant portion of the plankton assemblage during the anchovy spawning season (Alvariño 1980). Planktivorous fish are abundant in upwelling systems, and they are significant predators of fish eggs (MacCall 1980, Dann et al. 1985, Alheit 1987). Hunter $\&$ Kimbrell (1980) estimated that $17.2 \%$ of the population of northern anchovy eggs was removed by cannibalism; the impact on fish larvae is more difficult to assess due to the rapid digestion of the larvae by the fish. In the laboratory, it seems that predatory fishes mainly consume eggs and older, more visible fish larvae, whereas the yolk-sac stages are less vulnerable (Folkvord \& Hunter 1986, Pepin 1987, Margulies 1989).

Identifying the major predators of the young stages of fish and measuring and quantifying their impact is a massive undertaking. The immunochemical method offers a powerful approach for identifying potential crustacean predators and elevating the status of a potential predator to a positive one. Currently the ELISPOT immunoassay is being used to study predation by amphipods, mysiids, and euphausiids on the young stages of walleye pollock Theragra chalcogramma in the Gulf of Alaska (Bailey et al. in press).

Immunoassay surveys provide an important method to identify factors affecting recruitment processes. Thus, we feel it is essential to comment on the inherent limitations of the immunoassay and on the assumptions we made, and to make recommendations for future studies.

One limitation of our antiserum is that it does not differentiate between predators feeding on eggs or on yolk-sac larvae. Laboratory experiments show that euphausids and copepods mostly consume yolk-sac larvae, and that they appear to be ineffective predators on eggs (Hunter 1984). A possible reason for this result is that most pelagic eggs float on the surface in static laboratory containers and are unavailable to the predators. In the sea, where mixing occurs above the thermocline, Ahlstrom (1959) has shown that pelagic eggs are well distributed. Additionally in the field, Bailey et al. (unpubl.) have detected walleye pollock egg yolk protein in the guts of predatory invertebrates prior to the period of hatching.

Another limitation that complicates the quantification process is that the immunoassay, as applied in this study, yielded information only on the presence or absence of yolk protein in the predator's gut. Thus, in addition to not differentiating between egg and yolk-sac larvae, it did not distinguish between 1 or more prey having been eaten. Consequently, this approach is appropriate to study predators that have low daily consumption rates. Daily consumption rates measured in the laboratory for copepods, euphausiids, and amphipods range from 1 to 24 , albeit at prey densities higher than those that occur in the field (Hunter 1984, Bailey \& Houde 1989).

Spurious reactions could occur if the antisera crossreacts with yolk protein from other fish. Using our antibody preparation, we have obtained cross-reactions with dot blots of yolk from single eggs (ca $60 \mu \mathrm{g}$ yolk protein dry wt $\mathrm{egg}^{-1}$ ) of sardine Sardinops sagax Pacific mackerel Scomber japonicus and Pacific herring Clupea pallasi. However, we have additional experimental evidence that suggests yolk protein from other fish could not be detected in vivo.

We compared equivalent amounts of Pacific mackerel and anchovy yolk protein in an ELISPOT titre test. Side-by-side testing revealed a much reduced reaction for mackerel protein at all protein concentrations and 
no visible reaction at protein concentrations less than $0.3 \mu \mathrm{g}$. Thus, it appears Pacific mackerel yolk proteins have few antigenic sites in common with anchovy protein. Since we rarely find more than $0.3 \mu \mathrm{g}$ of anchovy yolk protein in euphausiid stomachs, presumably due to the degradation of the yolk protein by euphausiid proteolytic activity (an anchovy yolk-sac larvae contains about $6 \mu \mathrm{g}$ yolk protein; Theilacker et al. 1986), we assume that mackerel and other fish yolk proteins will behave similarly and that after digestion by euphausiids too few sites will be retained to elicit a visible reaction.

To determine whether cross-reactions occurred in the field samples, we collected and tested predators off California in November before peak anchovy spawning when other fish eggs and larvae were present (Fig. 5). Because most of the euphausiids (117/119, $98.3 \%$ ) tested negative, we did not consider crossreactions to be a problem.

We obtained a few spurious reactions outside the anchovy spawning area. Two Euphausia gibboides in November and 6 E. recurva in March, collected west of Stn 90 on lines 87 and 93 (Figs. 1, 2a, b), tested positive for anchovy yolk protein. We cannot explain these spurious reactions, but it is in the realm of possibilities that anchovy eggs from the western boundary of the spawning area could be entrained in eddys or filaments and relocated offshore. Fiedler (1986) deduced from satellite imagery and field information that in March of 1985 an eddy entrained and transported anchovy larvae to the same offshore area between lines 87 and 93. This was a recurrent eddy, found in an anomalous location in March 1985. The total time for transport to carry water offshore is not well known, although filament speeds of up to $0.7 \mathrm{~m} \mathrm{~s}^{-1}$ have been documented off central California (Strub et al. 1991). Speeds this strong could transport anchovy embryos offshore where the predators were collected within $6 \mathrm{~d}$, the period that yolk is retained in developing anchovy. Yet the collecting nets sampled no anchovy products in this offshore area. Perhaps euphausiids, which encounter larger spheres and integrate over longer time periods than nets do, are better samplers than nets. In any event, these few curious, positivereactive euphausiids contributed little to the overall estimate of the predation impact.

We made several assumptions which, if wrong, could modify the outcome. The calculation of the predatory impact of the euphausiid assemblage is sensitive to the functions describing ingestion and gut residence time. Here we used the measured rate for Euphausia pacifica gut residence time, and because little was known about this rate for the 5 other species studied, we ascribed the E. pacifica rate to them as well. Fifty percent of the euphausiids examined in this study were E. pac-

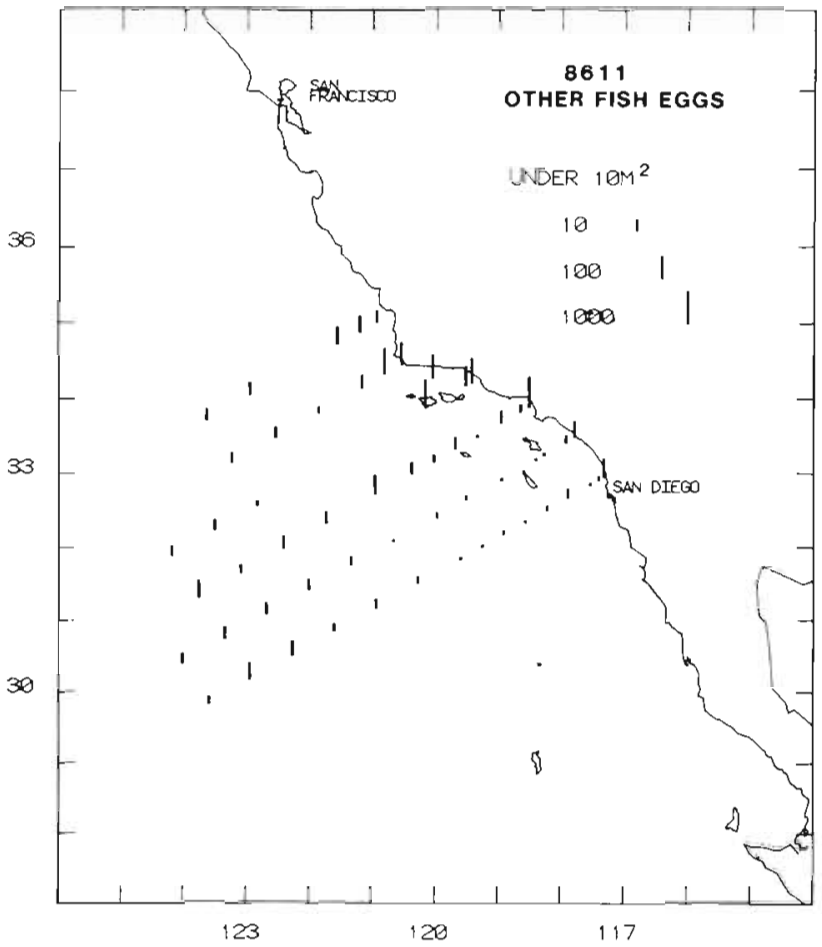

Fig. 5. Abundance of other fish eggs in November 1986. Egg numbers adjusted to equal the average abundance under $10 \mathrm{~m}^{2}$ of sea surface

ifica. The assumptions we made were: (1) the 6 to $11 \mathrm{~mm}$ size class of the investigated species feeds at the same rate as E. pacifica of that size; (2) gut residence time of anchovy yolk protein for the investigated euphausiids $>11 \mathrm{~mm}$ is the same as for E. pacifica $>11 \mathrm{~mm}$; and (3) gut residence time for the 6 to $11 \mathrm{~mm}$ group is 3 times that of euphausiids $>11 \mathrm{~mm}$.

Willason \& Cox (1987) determined the residence time for phytoplankton pigment in the guts of Euphausia pacifica $>11 \mathrm{~mm}$ after feeding them on charcoal particles. They used an exponential model to describe gut clearance. Using their model, we calculated that 3 to $5 \%$ of the initial pigment remained in the euphausiid guts after $3.5 \mathrm{~h}$, the average detection time determined for our experiments. Although they found that some plant pigment still could be measured in the guts for $10 \mathrm{~h}$, we found no detectable yolk protein after $6 \mathrm{~h}$. Thus, their measurements for gut residence time of phytoplankton prey for euphausiids $>11 \mathrm{~mm}$ differ somewhat from our gut clearance measurements for ichthyoplankton prey. Willason \& Cox (1987) did not study the smaller size class, and we could find no values in the literature for euphausiids $<11 \mathrm{~mm}$.

Clearly, further studies are needed to substantiate size-specific functions for ingestion and detection time for the primary predator species. An accurate measure 
of predation for the 6 to $11 \mathrm{~mm}$ size group is important. In our study area, the total number of 6 to $11 \mathrm{~mm}$ euphausiids at the low-predation stations was about 8 times the number of $>11 \mathrm{~mm}$ euphausiids. It is common for abundance of 6 to $11 \mathrm{~mm}$ euphausiids to be an order of magnitude higher than the $>11 \mathrm{~mm}$ size class (Brinton \& Wyllie 1976).

We believe our results are conservative. Predator abundance may be underestimated due to euphausiids avoiding the collecting net and to their contagious distributions that we discussed earlier. Additionally, we may have overestimated average detection time because $25 \%$ of the individuals tested in the laboratory had completely digested the protein within the $2 \mathrm{~h}$ feeding trial (see euphausiids at Hour 0, Fig. 4).

In the future, to resolve the potential cross-reaction dilemma, we suggest testing the gut contents of euphausiids fed in the laboratory on the eggs or larvae of other, co-occurring fishes. Ideally it would be hest to dedicate a cruise to this study and to take sufficient samples to confidently estimate mortality rates using only eggs and yolk-sac larvae.

Our study showed that euphausiids are important predators on the early life history stages of anchovy. The impact of the euphausiid population was substantial. Euphausiid crustaceans are ubiquitous in the sea and numerically one of the major planktonic organisms in the eastern north Pacific (Boden et al. 1955) having a great potential to impact all fish populations that spawn pelagic eggs.

Acknowledgements. It was Bob Feller's presentation at the 1981 Gut Shop Mceting in Monterey, CA, and earlier laboratory work at the Southwest Fisheries Science Center on euphausiid predation with Reuben Lasker and encouragement from John Hunter that inspired the senior author to examine the biochemical approach to answer the predation question. We thank the crew of the RV 'New Horizon' and the NOAA vessel 'David Starr Jordan' and the assistance of Bill Flerx, Ron Dotson and Anna Miranda during the field study. Marlene Johnson assisted with the immunoassays at the Southwest Fisheries Science Center. We appreciate the support of Gary Stauffer, Art Kendall and Kevin Bailey at the Alaska. Fisheres Science Center during the analysis and writing phase of this study. Mark Ohman, Kevin Bailey, and 2 anonymous reviewers critically reviewed the manuscript and offered valuable suggestions, and Susan Picquelle was always available for worthwhile discussions.

\section{LITERATURE CITED}

AhIstrom, E. H. (1959). Vertical distribution of pelagic fish eggs and larvae off California and Baja Calıfornia. U.S Fish Wildl. Serv. Fish. Bull 60: 107-146

Alhert, J. (1987). Egg cannibalism versus egg production: their significance in anchovies. S. Afr. J. mar. Sci. 5: $467-470$

Alvarino, A. (1980). The relation between the distribution of zooplankton predators and anchovy larvae. Calif. coop. oceanic Fish Invest. Rep. 21: 150-160

Alvariño, A. (1985). Predation in the plankton realmi mainly with reference to fish larvae. Invest. Mar. Centro interdisc. Cien. Mar. 2: 1-122

Antezana, T., Ray, K., Melo, C. (1972\}. Trophic behavior of Euphausia superba Dana in laboratory conditions. Pol. Biol. 1: 77-82

Bailey, K. M., Brodeur, R. D., Merati, N., Yoklavich, M. M. (in press). Predation on walleye pollock (Theragra chalcogramma) eggs and yolk-sac larvae by pelagic crustacean invertebrates in the western Gulf of Alaska. Fish. Oceanogr.

Bailey, K. M., Houde, E. D. (1989). Predation on eggs and larvae of marine fishes and the recruitment problem. Adv. mar. Biol. 25: 1-83

Bailey, K. M., Yen, J. (1983). Predation by a carnivorous marine copepod, Euchaeta elongata Esterly, on eggs and larvae of the Pacific hake, Merluccius productus. J. Plankton Res. 5: 71-82

Boden, B. P., Johnson, M. W., Brinton, E. (1955). The Euphausiacea (Crustaced) of the North Pacific. Bull. Scripps insin Oceanoyt. 6: 247-400

Boreham, P. F. L., Ohiagu, C. E. (1978). The use of serology in evaluating invertebrate prey-predator relationships: a review. Bull. entomol. Res. 68: 171-194

Brinton, E. (1962). The distribution of Pacific euphausiids. Buil. Scripps Insin Oceanogr. 8: 51-270

Brinton, E. (1967). Vertical migration and avoidance capability of euphausiids in the California Current. Limnol. Oceanogr. 12: 451-483

Brinton, E. (1976). Population biology of Eupausia pacifica off southern California. Fish. Bull. U.S. 74: 733-762

Brinton, E., Wyllie, J. G. (1976). Distributional atlas of euphausiid growth stages off southern California, 1953 through 1956. Calif. coop. oceanic Fish. Invest. Atlas No. 24

Brownell, C. L. (1985). Laboratory analysis of cannibalism by larvae of the cape anchovy Engraulis capensis. Trans. Am. Fish. Soc. 114: 512-51.8

Calver, M. C. (1984). A review of ecological applications of immunological techniques for diet analysis. Aust. J. Ecol. 9: $19-25$

Daan, N., Rijnsdorp, A. D., van Overbeeke, G. R. (1985). Predation by North Sea herring Clupea harengus on eggs of plaice Pleuronectes platessa and cod Gadus morhua. Trans. Am. Fish. Soc. 114:499-506

de Lafontaine, Y., Leggett, W. C. (1988). Predation by jellyfish on larval fish: an experimental evaluation employing in situ enclosures. Can. J. Fish. Aquat. Sci. 45: $1173-1190$

Endo, Y., Hanamura, Y., Taniguchi, A. (1985). In situ observations on the surface swarm of Euphausia pacifica in Sendai Bay in edrly spring with special reference to their biological characteristics. La Mer 23: 135 140

Feller, R. J., Taghon, G. L., Gallagher, E. D., Jumars, P. A. (1979). Immunological methods for food web analysis in a soft-bottom benthic community. Mar Biol. 54 . $61-74$

Fiedler, P. C. (1986). Offshore entrainment of anchovy spawning habitat, eggs, and larvae by a displaced eddy in 1985. Calif. coop. oceanic Fish. [nvest. Rep. 27: 144-152

Folkvord, A., Hunter, J. R. (1986). Size-specific vulnerabilıty of northern anchovy, Engraulis mordax, larvae to predation by fishes. Fish. Bull. U.S. 84: 859-869

Hunter, J. R. (1.984). Inferences regarding predation on the early life stages of cod and other fishes. The propagation 
of cod, Gadus morhua L. Flodevigen rapportser. 1 $533-562$

Hunter, J. R., Kimbrell, C. A. (1980). Egg cannibalism in the northern anchovy, Engraulis mordax. Fish. Bull. U.S. 78: $811-816$

Isaacs, J. D., Flemminger, A., Miller, J. K. (1969). Distributional atlas of zooplankton biomass in the California Current region: spring and fall 1955-1959. Calif. coop. oceanic Fish. Invest. Atlas No. 10: V-XXV, $1-252$

Komaki, Y (1967). On the surface swarming of euphausiid crustaceans. Pacif. Sci. 21: 433-448

Lasker, R. (1966). Feeding, growth, respiration and carbon utilization of a euphausiid crustacean. J. Fish. Res. Bd Can. 23: 1291-1317

Lillelund, K., Lasker, R. (1971). Laboratory studies of predation by marine copepods on fish larvae. Fish. Bull. U.S. 69 : 655-667

Lo, N. C. H. (1983). Re-estimation of three parameters associated with anchovy egg and larval abundance: temperature dependent incubation time, yolk-sac growth rate, and egg and larval retention in mesh nets. U.S. Dept Commerce, NOAA Tech Memo. NMFS F/SWFC-31

Lo, N. C. H. (1985). A model for temperature-dependent nothern anchovy egg development and an automated procedure for the assignment of age to staged eggs. In: Lasker, R. (ed.) An egg production method for estimating spawning biomass of pelagic fish: application to the northern anchovy, Engraulis mordax. NOAA Tech. Rep. NMFS 36: $43-50$

Lo, N. C. H. (1986). Modeling life-stage-specific instantaneous mortality rates, an application to northern anchovy, Engraulis mordax, eggs and larvae. Fish. Bull. U.S. 84: 395

MacCall, A. D. (1980). The consequences of cannibalism in the stock-recruitment relationship of planktivorous fishes such as Engraulis. FAO, International Oceanographic Commision Workshop Report 28: 201-220

Margulies, D. (1989). Size-specific vulnerability to predation and sensory system development of white seabass, Atractoscion nobilis, larvae. Fish. Bull. U.S. 87: 537-552

Mauchline, J. (1967). Feeding appendages of the Euphausiacea (Crustacea). J. Zool 153: 1-43

McClatchie, S. (1985). Feeding behaviour in Meganyctiphanes novegica (M. Sars) (Crustacea; Euphausiacea). J. exp. mar. Biol. Ecol. 86: 271-284

McGurk, M. D. (1986). Natural mortality of marine pelagic fish eggs and larvae: role of spatial patchiness. Mar. Ecol. Prog. Ser. 34: 227-242

Methot, R. D., Hewitt, R. P. (1980). A generalized growth curve for young anchovy larvae: derivation and tabular example. NMFS, SWFC Admin. Rep. LJ-80-17

Moller, H. (1984). Reduction of a larval herring population by jellyfish predator. Science 224: 621-622

Moser, H. G., Ahlstrom, E. H. (1985). Staging anchovy eggs In: Lasker, R. (ed.) An egg production method for estimating spawning biomass of pelagic fish: application to the northern anchovy, Engraulis mordax. NOAA Tech. Rep. NMFS 36: $37-41$

Nicol, S. (1984). Cod end feeding by the euphausiid Meganyctiptianes norvegica. Mar. Biol. 80: 29-33

Ohman, M. D. (1984). Omnivory by Euphausia pacifica: the role of copepod prey. Mar. Ecol. Prog. Ser. 19: 125-131

Ohman, M. D., Theilacker, G. H., Kaupp, S. E. (1991). Immunochemical detection of predation on ciliate protists by larvae of the northern anchovy (Engraulis mordax). Biol. Bull. 181: 500-504
Pepin, P. (1987). Influence of alternative prey abundance on pelagic fish predation of larval fish: a model. Can. J. Fish. Aquat. Sci. 44: 222-227

Peterman, R. M. Gatto, M. (1987). Estimation of functional responses of predators on juvenile salmon. J. Fish. Res. Bd Can. 35: 797-808

Purcell, J. E. (1985). Predation on fish eggs and larvae by pelagic cnidarians and ctenophores. Bull. mar. Sci. 37: $739-755$

Purcell, J. E. (1989). Predation on fish larvae and eggs by the hydromedusa Aequorea victoria at a herring spawning ground in British Columbia. Can. J. Fish. Aquat. Sci. 46: $1415-1427$

Purcell, J. E. (1990) Soft-bodied zooplankton predators and competors of larval herring (Clupea harengus pallasi) at herring spawning grounds in British Columbia. Can. J. Fish. Aquat. Sci. 47: 505-515

Ross, R. M. (1982). Energetics of Euphausia pacifica. I. Effects of body carbon and nitrogen and temperature on measured and predicted production. Mar. Biol. 68: 1-13

Sissenwine, M. P. (1984). Why do fish populations vary? In: May, R. (ed.) Exploitation of marine communities. Springer-Verlag, Berlin, p. 59-94

Smith, P. E., Flerx, W., Hewitt, R. P. (1985). The CalCOFI vertical egg tow (CalVET) net. NOAA Tech. Rep. NMFS 36: $27-32$

Smith, P. E., Richardson, S. L. (1977). Standard techniques for pelagic fish egg and larva surveys. FAO, Fish. Tech. Pap. 175: $1-100$

Smith, S. E., Adams, P. B. (1988). Daytime surface swarms of Thysanoessa spinifera (euphausiacea) in the Gulf of the Farallones, California. Bull. mar. Sci. 42(1): 76-84

Strub, P. T., Kosro, P. M., Huyer, A. (1991). The nature of the cold filaments in the California Current System. J. geophys. Res. 96: 14743-14768

Stuart, V. (1986). Feeding and metabolism of Euphausia lucens (euphausiacea) in the southern Benguela current. Mar. Ecol. Prog. Ser. 30: 117-125

Stuart, S. E., Pillar, S. C. (1990). Diel grazing patterns of all ontogenetic stages of Euphausia lucens and in situ predation rates on copepods in the southern Benguela upwelling region. Mar. Ecol. Prog. Ser. 64: 227-241

Sunderland, K. D. (1988). Quantitative methods for detecting invertebrate predation occurring in the field. Ann. appl. Biol. 112: 201-224

Theilacker, G. H. (1988). Euphausiid predation on larval anchovy at two contrasting sites off California determined with an ELISPOT immunoassay. In: Yentsch, C. M., Mague, F. C., Horan, P. K. (eds.) Lecture notes on coastal and estuarine studies, Vol. 25. 'Immunochemical approaches to coastal, estuarine and oceanographic questions'. Springer-Verlag, Berlin, p. 304-311

Theilacker, G. H. (1980). Changes in the body measurements of larval northern anchovy, Engrualis mordax, and other fishes due to handling and preservation. Fish. Bull. U.S. 78: 685-692

Theilacker, G. H., Kimball, A. S., Trimmer, J. S. (1986). Use of an ELISPOT immunoassay to detect euphausiid predation on larval anchovy. Mar. Ecol. Prog. Ser. 30: 127-131

Theilacker, G. H., Lasker, R. (1974). Laboratory studies of predation by euphausiid shrimps on fish larvae. In: Blaxter, J. H. S. (ed.). The early life history of fish. Springer-Verlag, Berlin, p. 287-299

Willason, S. W., Cox, J. L. (1987). Diel feeding, laminarinase activity and phytoplankton consumption by euphausiids. Biol. Oceanogr. 4: 1-24

Yamashita, Y., Kitagawa, D., Aoyama, T. (1985). A field study 
of predation of the hyperiid amphipod Parathemisto japonica on larvae of the japanese sand eel Ammodytes personatus. Bull. Jap. Soc. scient. Fish. 51. 1599-1607

This article was submitted to the editor
Yen, J. (1987). Predation by a carnivorous copepod, Euchaeta norvegica Boeck, on eggs and larvae of the North Atlantic cod Gadus mohua L. J. exp. mar. Ecol. 112: 283-296

Manuscript first received: June 15, 1992

Revised version accepted: November 9, 1992 